\title{
Suxiao Jiuxin Pill protects cardiomyocytes against mitochondrial injury and alters gene expression during ischemic injury
}

\author{
XIAOFEN RUAN, TIEJUN CHEN, XIAOLONG WANG and YIPING LI \\ Cardiovascular Department, Shuguang Hospital Affiliated to Shanghai University \\ of Traditional Chinese Medicine, Shanghai 201203, P.R. China
}

Received September 28, 2016; Accepted June 16, 2017

DOI: $10.3892 /$ etm.2017.4964

\begin{abstract}
Suxiao Jiuxin Pill (SX), a traditional Chinese medicine compound consisting primarily of tetramethylpyrazine and borneol, has been reported to protect against ischemic heart disease. However, the effects of SX on mitochondrial injury and gene expression in various signaling pathways are unclear. The aim of the present study was to investigate the effects of SX on mitochondrial injury and to screen the expression of genes potentially altered by SX using a cell culture model of ischemic injury. Simulated ischemia was established by culturing HL-1 cardiomyocytes in Dulbecco's modified Eagle's medium without glucose or serum in a hypoxic chamber containing $95 \% \mathrm{~N}_{2}$ and $5 \% \mathrm{CO}_{2}$ for $24 \mathrm{~h}$. HL-1 cardiomyocytes were divided into 3 groups: Control, ischemic injury and ischemic injury + SX (100 $\mu \mathrm{g} / \mathrm{ml} ; \mathrm{n}=3$ wells/group). Mitochondrial membrane potential was detected by staining with JC-1 dye. The mRNA expression levels of adenylyl cyclase (Adcy) 1-9, adrenoceptor $\beta 1$, Akt1, ATPase $\mathrm{Na}+\mathrm{K}+$ transporting subunit $\beta 2$, calcium voltage-gated channel auxiliary subunit $\alpha 2 \delta$ (Cacna2d)2, Cacna2d3, calcium channel voltage-dependent $\gamma$ subunit 8 , cytochrome $\mathrm{C}$ oxidase subunit 6A2 (Cox6a2), fibroblast growth factor receptor (Fgfr) 4, Fgf8, Fgf12, Gnas complex locus, glycogen synthase kinase $3 \beta$ (Gsk3b), mitogen-activated protein kinase (Mapk)11-14, Mapk kinase kinase kinase 1 (Map4k1), Mas1, nitric oxide synthase 3 (Nos3), phosphatidylinositol-4,5-bisphosphate 3-kinase catalytic subunit $\alpha$ (Pik3ca), phospholipase A2 group 4A, rap guanine nucleotide exchange factor 4 and ryanodine receptor 2 were detected using reverse transcription-quantitative polymerase chain reaction. The protein expression levels of phosphoinositide 3-kinase (PI3K), MAS-1 and phosphorylated-endothelial NOS were also examined by immunofluorescence staining. The
\end{abstract}

Correspondence to: Dr Xiaolong Wang, Cardiovascular Department, Shuguang Hospital Affiliated to Shanghai University of Traditional Chinese Medicine, 528 Zhangheng Road, Shanghai 201203, P.R. China

E-mail: wxlqy0214@163.com

Key words: Suxiao Jiuxin Pill, HL-1 cells, ischemic injury, mitochondria, mRNA decrease in mitochondrial membrane potential in the cell culture model of ischemic injury $(\mathrm{P}<0.001)$ was significantly attenuated by $\mathrm{SX}$ treatment $(\mathrm{P}<0.001)$. Furthermore, increases in the mRNA expression levels of Adcy2 $(\mathrm{P}<0.05), 3(\mathrm{P}<0.01)$ and $8(\mathrm{P}<0.05)$ in the ischemic injury model were significantly attenuated by SX treatment $(\mathrm{P}<0.01)$, and SX treatment significantly decreased the mRNA expression levels of Adcyl $(\mathrm{P}<0.01)$ and $6(\mathrm{P}<0.05)$ in ischemic cells. Decreases in the mRNA expression levels of Cox6a2 ( $\mathrm{P}<0.001)$, Gsk3b $(\mathrm{P}<0.01)$ and Pik3ca $(\mathrm{P}<0.001)$ in the ischemic injury model were also significantly attenuated by $\mathrm{SX}$ treatment $(\mathrm{P}<0.05, \mathrm{P}<0.01$ and $\mathrm{P}<0.001$, respectively). In addition, the decrease in the protein expression of PI3K ( $<<0.001)$ was significantly attenuated by SX treatment $(\mathrm{P}<0.001)$. The present findings indicate that $\mathrm{SX}$ may protect cardiomyocytes against mitochondrial injury and attenuate alterations in the gene expression of Adcy2, 3 and 8, Cox6a2, Gsk3b and Pik3ca during ischemic injury.

\section{Introduction}

Ischemic heart disease (IHD), also known as coronary artery disease, includes conditions such as stable angina, unstable angina, myocardial infarction and sudden cardiac arrest (1) IHD is the most common type of cardiovascular disease, and its mortality rate has recently been increasing (2). In 2010, IHD was the cause of 7 million mortalities worldwide; an increase of 35\% since $1990(3,4)$. Current management of IHD includes lifestyle changes, coronary interventions, coronary artery bypass grafting and medication, including cholesterol lowering agents, beta-blockers, nitroglycerin and calcium channel blockers (5).

Suxiao Jiuxin Pill (SX), a traditional Chinese medicine compound that primarily consists of tetramethylpyrazine and borneol, is commonly prescribed alongside standard management strategies for IHD in China (6). SX has been reported to protect against IHD in clinical and animal studies $(7,8)$. Among patients with acute coronary syndrome undergoing early percutaneous coronary intervention, the incidence of perioperative myocardial infarction was significantly lower in those who received SX treatment when compared with a placebo group (6). In addition, SX improved hemodynamic and myocardial oxygen metabolism, and reduced the degree and scope of myocardial ischemia in a dog model of coronary artery occlusion (8). However, the molecular mechanisms underlying 
the protective effects of SX on IHD and cardiomyocytes are largely unknown.

Mitochondria are a major target in hypoxic injury (9). The organelles are the final regulators of cell survival and death due to their role in ATP generation and ability to trigger apoptosis and necrosis (10). However, the effects of SX on mitochondrial injury in hypoxic injury remain to be fully elucidated. Membrane-related structures, including receptors, $G$ protein and enzymes, which are present in the plasma, mitochondrial and sarcoplasmic reticulum membranes, serve an important role in signal transduction in cardiomyocytes (11). However, it is currently unclear whether SX exerts effects on the proliferation of cardiomyocytes or nitric oxide (NO)-associated muscle relaxation during ischemic injury.

The present study used a cell culture model of ischemic injury to examine the effects of SX on mitochondrial membrane potential and the expression of genes associated with membrane structures and signals, namely adenylyl cyclase (Adcy), adrenoceptor $\beta 1$ (Adrb1), ATPase $\mathrm{Na}+/ \mathrm{K}+$ transporting subunit $\beta 2$ (Atp1b2), calcium voltage-gated channel auxiliary subunit $\alpha 2 \delta$ (Cacna2d)2, Cacna2d3, calcium channel voltage-dependent $\gamma$ subunit 8 (Cacng8), cytochrome $\mathrm{C}$ oxidase subunit 6A2 (Cox6a2), Gnas, phospholipase A2 group 4A (Pla2g4a) and ryanodine receptor 2 (Ryr2) (12-14). In addition, the expression of genes associated with cell proliferation, namely Akt1, fibroblast growth factor receptor (Fgfr)4, 8 and 12, glycogen synthase kinase $3 \beta$ (Gsk3b), mitogen-activated protein kinase (Mapk)11-14, Mapk kinase kinase kinase 1 (Map4k1), Mas1 and phosphatidylinositol-4,5-bisphosphate 3-kinase catalytic subunit $\alpha$ (Pik3ca) was evaluated (15-17). Furthermore, genes associated with $\mathrm{NO}$-associated muscle relaxation, including nitric oxide synthase 3 (Nos3) and rap guanine nucleotide exchange factor 4 (Rapgef4), were investigated $(18,19)$. These methods aimed to determine the effects of SX on mitochondrial injury and gene expression in a cell model of ischemic injury.

\section{Materials and methods}

Cells, reagents and equipment. A mitochondria membrane potential kit (Beyotime Institute of Biotechnology, Shanghai, China); Dulbecco's modified Eagle's medium (DMEM; Gibco; Thermo Fisher Scientific, Inc., Waltham, MA, USA); fetal bovine serum (FBS; Bio-west, Inc., North Logan, UT, USA); anti-MAS1 (ab197992), anti- phosphoinositide 3-kinase (PI3K; ab40776) and anti-phosphorylated (p)-endothelial(e)NOS primary antibodies (ab95254; all from Abcam, Cambridge, MA, USA); primers (Invitrogen; Thermo Fisher Scientific, Inc.); RNeasy Mini kit (Qiagen, Inc., Valencia, CA, USA); TRIzol Reagent (Invitrogen; Thermo Fisher Scientific, Inc.); chloroform; isopropanol; 75\% anhydrous ethanol (all from Sinopharm Chemical Reagent, Inc., Shanghai, China); diethyl pyrocarbonate $\mathrm{H}_{2} \mathrm{O}$ (used for RNA extraction); SuperScript III Reverse Transcriptase; SYBR Green I (all from Invitrogen; Thermo Fisher Scientific, Inc.); RNase inhibitor (Fermentas; Thermo Fisher Scientific, Inc.); oligo dT/primer; Platinum Taq DNA Polymerase; and $100 \mathrm{mM}$ dNTPs (all Invitrogen; Thermo Fisher Scientific, Inc.) were used in the present study.

Equipment used in the present study included a cell incubator (Thermo Fisher Scientific, Inc.); light and fluorescence microscopes (Olympus Corporation; Tokyo, Japan); a table-type refrigerated centrifuge (Zhengzhou Nanbei Instrument Equipment Inc., Zhengzhou, China); and a CFX96 Touch ${ }^{\text {TM }}$ Real-Time PCR Detection System (Bio-Rad Laboratories, Inc., Hercules, CA, USA).

HL-1 murine cardiomyocytes (Novobio Scientific, Inc., Shanghai, China) were cultured in DMEM supplemented with $10 \%$ FBS, $0.1 \mathrm{mM}$ norepinephrine, $2 \mathrm{mM}$ glutamine, $100 \mathrm{U} / \mathrm{ml}$ penicillin, $100 \mathrm{U} / \mathrm{ml}$ streptomycin and $0.25 \mathrm{mg} / \mathrm{ml}$ amphotericin $\mathrm{B}$ at $37^{\circ} \mathrm{C}$ in a cell incubator containing $5 \% \mathrm{CO}_{2} . \mathrm{SX}$ (40 mg/tablet; Tianjin Zhongxin Pharmaceutical Inc., Tianjin, China) was principally composed of Chuan Xiong (Rhizoma Chuanxiong) and Borneolum Syntheticum. SX was ground into a powder and dissolved in phosphate buffered saline (PBS) to a final concentration of $100 \mu \mathrm{g} / \mathrm{ml}$.

Experimental design and cell culture model of ischemic injury. Simulated ischemia was established by culturing HL-1 cardiomyocytes $\left(1 \times 10^{4}\right.$ cells $\left./ \mathrm{ml}\right)$ in DMEM without glucose or serum in a hypoxic chamber containing 95\% $\mathrm{N}_{2}$ and $5 \%$ $\mathrm{CO}_{2}$ for $24 \mathrm{~h}$ at $37^{\circ} \mathrm{C}$. HL-1 cardiomyocytes were divided into 3 groups: Control, ischemic injury, and ischemic injury + SX ( $n=3$ wells/group). To determine the optimal SX dosage, SX $(10,50,100,200$ and $400 \mu \mathrm{g} / \mathrm{ml}$, respectively) was added to the cell culture medium for $24 \mathrm{~h}$ at $37^{\circ} \mathrm{C}$ immediately before hypoxia. Cell morphology was observed using light microscopy. Among all the dosages, $100 \mu \mathrm{g} / \mathrm{ml} \mathrm{SX} \mathrm{induced} \mathrm{optimal}$ growth (fewest dead cells per microscopic field) of the HL-1 cardiomyocytes, indicating that the protective effects of SX against ischemic injury were greatest at this dosage (Fig. 1). Therefore, $100 \mu \mathrm{g} / \mathrm{ml}$ of SX was used in the following experiments. Cells in the control group were cultured in DMEM supplemented with $10 \mathrm{mM}$ glucose and $10 \% \mathrm{FBS}$ in a normoxic chamber containing $5 \% \mathrm{CO}_{2}$ for $24 \mathrm{~h}$ at $37^{\circ} \mathrm{C}$.

Detection of mitochondrial membrane potential. HL-1 cardiomyocytes in the 3 groups were cultured in 24-well plates, and treated as described above. A mitochondrial membrane potential kit was utilized to detect mitochondrial membrane potential. Cells were washed with DMEM medium once, and $0.25 \mathrm{ml}$ fresh DMEM medium supplemented with $10 \mathrm{mM}$ glucose and $10 \%$ FBS was added into each well. JC-1 dye ( $0.25 \mathrm{ml}$; from mitochondria membrane potential kit) was added into each well and mixed thoroughly. Cells were subsequently incubated in an incubator at $37^{\circ} \mathrm{C}$ for $20 \mathrm{~min}$. At the end of incubation, culture supernatant was discarded and cells were washed with PBS (3 times, $30 \mathrm{sec} /$ wash). Cell culture medium $(0.5 \mathrm{ml})$ was added, and cells were observed using a fluorescence microscope. Integrated optical density (IOD) was calculated by multiplying the area (size) and average density of fluorescence (20). Samples were evaluated using Image-Pro Plus 7 software (Media Cybernetics Inc., Rockville, MD, USA).

Reverse transcription-quantitative polymerase chain reaction (RT-qPCR). Total RNAs from HL-1 cardiomyocytes in the control, ischemic injury, and ischemic injury + SX groups were extracted and purified using TRIzol, following the manufacturer's instructions. RNase inhibitor was utilized in order to reduce the degradation of RNA. A universal cDNA synthesis kit (Invitrogen; Thermo Fisher Scientific, Inc.) was utilized for 

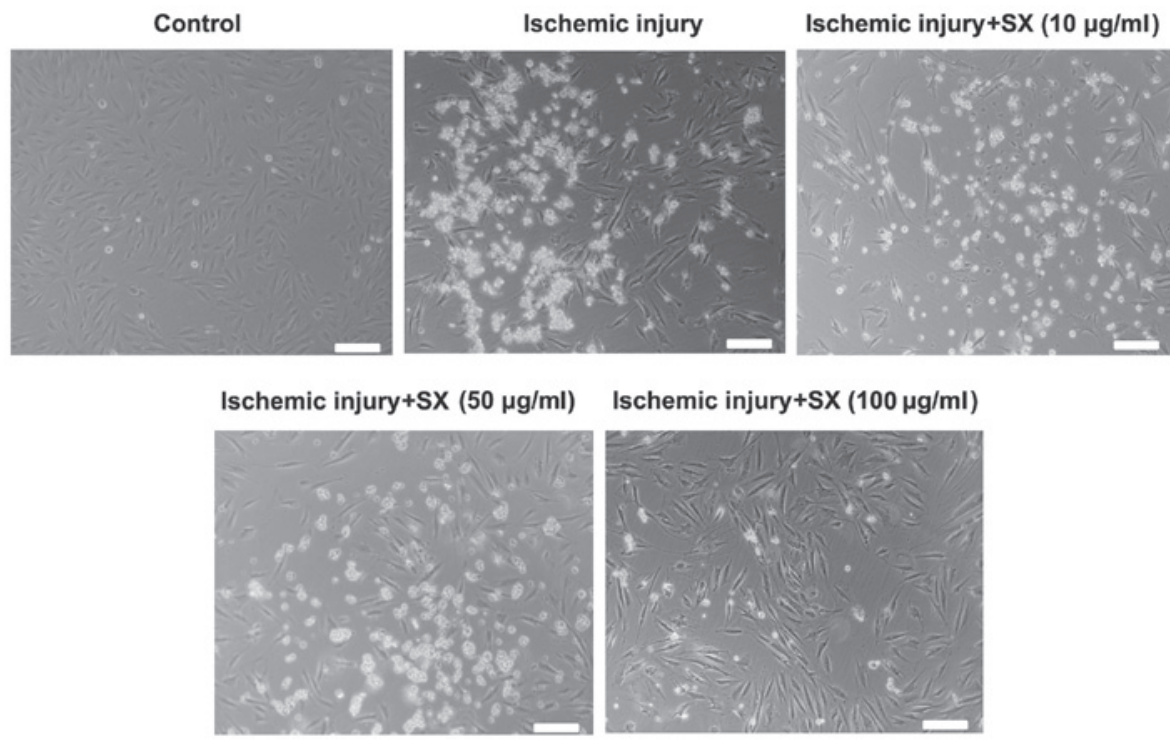

Ischemic injury+SX $(200 \mu \mathrm{g} / \mathrm{ml})$ Ischemic injury+SX $(400 \mu \mathrm{g} / \mathrm{ml})$
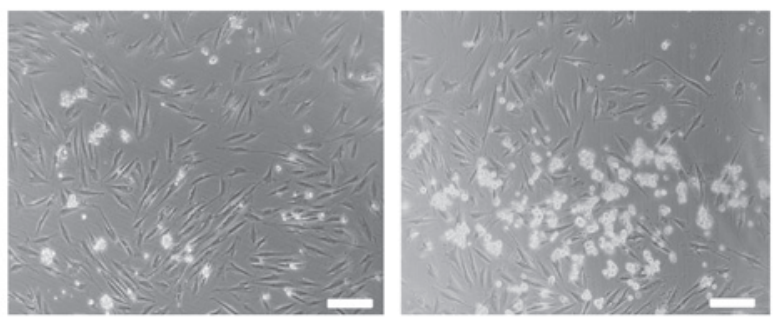

Figure 1. Determination of the optimal dosage of SX. HL-1 cardiomyocytes were divided into 3 groups: Control, ischemic injury, and ischemic injury + SX. Induced ischemia was established by culturing HL-1 cardiomyocytes in glucose- and serum-free Dulbecco's modified Eagle's medium in a hypoxic chamber with $95 \% \mathrm{~N}_{2}$ and $5 \% \mathrm{CO}_{2}$ for $24 \mathrm{~h}$. Cells in the control group were cultured in Dulbecco's modified Eagle's medium containing glucose and serum in a normoxic chamber with 5\% $\mathrm{CO}_{2}$ for $24 \mathrm{~h}$. To determine the optimal SX dosage, $\mathrm{SX}(10,50,100,200$ and $400 \mu \mathrm{g} / \mathrm{ml}$, respectively) was added to cell culture medium at the start of hypoxia. Cell morphology was observed using light microscopy. The growth of HL-1 cardiomyocytes was optimal following treatment with $100 \mu \mathrm{g} / \mathrm{ml}$ $\mathrm{SX}$, which indicated that $100 \mu \mathrm{g} / \mathrm{ml} \mathrm{SX}$ exerted the greatest protective effects against ischemic injury. Therefore, $100 \mu \mathrm{g} / \mathrm{ml} \mathrm{SX}$ was used for subsequent experiments. Magnification, x100; scale bar $=100 \mu \mathrm{m}$. SX, Suxiao Jiuxin Pill.

reverse transcription according to the manufacturer's instructions. Each reaction contained $0.5 \mu 1$ of oligo dT/primers $(0.2 \mu \mathrm{g} / \mu \mathrm{l})$ and $1 \mu \mathrm{l}$ of SuperScript III reverse transcriptase (200 U/ $\mu 1)$. The specific primers used for qPCR for Adcy1, Adcy2, Adcy3, Adcy4, Adcy5, Adcy6, Adcy7, Adcy8, Adcy9, Adrb1, Akt1, Atp1b2, Cacna2d2, Cacna2d3, Cacng8, Cox6a2, Fgfr4, Fgf8, Fgf12, Gnas, Gsk3b, Mapk11, Mapk12, Mapk13, Mapk14, Map4k1, Mas1, Nos3, Pik3ca, Pla2g4a, Rapgef4, Ryr2 and $\beta$-actin genes are listed in Table I. qPCR was performed by utilizing mRNA qPCR Detection kit. SYBR Green I, Platinum Taq DNA Polymerase and $100 \mathrm{mM}$ dNTPs were utilized in the experiment. The following PCR conditions were used: Pre-denaturing at $95^{\circ} \mathrm{C}$ for $2 \mathrm{~min}$; denaturing at $95^{\circ} \mathrm{C}$ for $10 \mathrm{sec}$; and annealing and polymerization at $60^{\circ} \mathrm{C}$ for $30 \mathrm{sec}$ and $70^{\circ} \mathrm{C}$ for $45 \mathrm{sec}$. A total of 40 PCR cycles were performed. PCR was conducted using a CFX96 Touch ${ }^{\mathrm{TM}}$ Real-Time PCR Detection System. Gene expression was determined as the relative optical density ratio between target gene and $\beta$-actin. The $\Delta \Delta \mathrm{C}_{\mathrm{q}}$ method was used to quantify gene expression (21).

Immunofluorescence. HL-1 cardiomyocytes in the 3 groups were treated as described above and cultured in 24-well plates for $24 \mathrm{~h}$ at $37^{\circ} \mathrm{C}$ with cover slips. Cells adhered to the cover slips were fixed in $4 \%$ paraformaldehyde (room temperature,
10 min), blocked with bovine serum albumin (Biowest USA, Riverside, MO, USA) at room temperature for $30 \mathrm{~min}$, and incubated with primary antibodies against MAS1, p-eNOS, and PI3K (all antibodies: 1:500) at $4^{\circ} \mathrm{C}$ overnight. Following overnight incubation, cover slips were washed with PBS and incubated in the dark with fluorescein isothiocyanate-conjugated goat anti-rabbit secondary antibody (1:1,000; Abcam; ab6717) at room temperature for $1 \mathrm{~h}$. Cover slides were subsequently washed with PBS (3 times, $30 \mathrm{sec} /$ wash) and stained with 4',6-diamidino-2-phenylindole for $5 \mathrm{~min}$ at room temperature. Slides were prepared with Mounting Media and Antifades (Invitrogen; Thermo Fisher Scientific, Inc.) and observed using a fluorescence microscope. The IOD, calculated by multiplying the area (size) and average density of fluorescence, was evaluated using Image-Pro Plus 7 software (20).

Statistical analysis. Experimental results were presented as the mean + standard error of the mean. One-way analysis of variance was used to compare differences among the 3 groups, followed by a Bonferroni post hoc test for multiple comparisons. $\mathrm{P}<0.05$ was considered to indicate a statistically significant difference. Statistical analysis was performed with GraphPad Prism 5.0 software (GraphPad Software Inc., La Jolla, CA, USA). 
Table I. Primers used in reverse transcription-quantitative polymerase chain reaction.

Primers Direction Sequences, 5'-3'

\begin{tabular}{|c|c|c|c|c|c|}
\hline & \multirow{2}{*}{ Primers } & \multirow{2}{*}{ Direction } & \multirow{2}{*}{ Sequences, 5'-3' } \\
\hline & & & & & \\
\hline Primers & Direction & Sequences, $5^{\prime}-3^{\prime}$ & \multirow{2}{*}{ Mas1 } & $\mathrm{F}$ & TCTGCTGACAGCCATCAGTG \\
\hline \multirow[t]{2}{*}{ Adcy1 } & $\mathrm{F}$ & GTCGGATGGATAGCACTGGG & & $\mathrm{R}$ & ACCAAGAAGCTGAGGATGGC \\
\hline & $\mathrm{R}$ & TAGCATCTCTCCCTTGCCCT & \multirow[t]{2}{*}{ Nos3 } & $\mathrm{F}$ & CTGTATGGCTCTGAGACTGGC \\
\hline \multirow[t]{2}{*}{ Adcy 2} & $\mathrm{~F}$ & GGAGTGCATTCTGGGAACG & & $\mathrm{R}$ & GCAGGAGACACTGTTGAATCGGA \\
\hline & $\mathrm{R}$ & AGAGATGCTGAGGACTCCGT & \multirow[t]{2}{*}{ Pik3ca } & $\mathrm{F}$ & GCAGGGTTTTCTGTCCCCTC \\
\hline \multirow[t]{2}{*}{ Adcy3 } & $\mathrm{F}$ & AAAAGGCAGCGCCATGAGA & & $\mathrm{R}$ & CCAGATGTTCTCCATGATTCGGA \\
\hline & $\mathrm{R}$ & TGATGTCCAACACCAGACCG & \multirow[t]{2}{*}{$\mathrm{Pla} 2 \mathrm{~g} 4 \mathrm{a}$} & $\mathrm{F}$ & GTTCAGCATGGCACTGTGTG \\
\hline \multirow[t]{2}{*}{ Adcy 4} & $\mathrm{~F}$ & TACCTGGCCCGAGAGATGAA & & $\mathrm{R}$ & GAACCCAAAATGGCCACCAC \\
\hline & $\mathrm{R}$ & AGCACACTCACTCCTTGGTG & \multirow[t]{2}{*}{ Rapgef4 } & $\mathrm{F}$ & ATAAAAGGCCGTTGGAGCGA \\
\hline \multirow[t]{2}{*}{ Adcy5 } & $\mathrm{F}$ & CCATCACCCTGGTGTTCCTC & & $\mathrm{R}$ & GACTCTCCAAAGGCTGTCCC \\
\hline & $\mathrm{R}$ & TTGAAGGCCGACTCCATCAC & \multirow[t]{2}{*}{ Ryr2 } & $\mathrm{F}$ & ATCTGCACCTTTGTGCTGGAGC \\
\hline \multirow[t]{2}{*}{ Adcy6 } & $\mathrm{F}$ & GGAGCAGTGCATTGAGACCT & & $\mathrm{R}$ & TCCATAGAGGAGTGTCCGGTGG \\
\hline & $\mathrm{R}$ & TAGAGTCCTTGGTCCGGGAG & \multirow{3}{*}{$\beta$-actin } & F & AGAAAATCTGGCACCACACC \\
\hline \multirow[t]{2}{*}{ Adcy 7} & $\mathrm{~F}$ & CACAGTCAATGTTGCCAGCC & & $\mathrm{R}$ & AGAGGGTACAGGGATAGCA \\
\hline & $\mathrm{R}$ & ССССТTTGCCTTTGACGTTG & & & \\
\hline
\end{tabular}

Adcy8 $\quad$ F CCTGGGGGACTGCTACTACT

$\mathrm{R}$ CTCCCAGGGATTCCTCCAGA

Adcy9 F TCTCAGGTGAGGTCCAGGAG

$\begin{array}{lll} & \mathrm{R} & \text { GTTCTTGGGACTGGAGGTGG } \\ \text { Adrb1 } & \mathrm{F} & \text { CTACAACGACCCCAAGTGCT }\end{array}$

R CTCGCAGCTGTCGATCTTCT

Akt1 F ATAACGGACTTCGGGCTGTG

R CCTGGTTGTAGAAGGGCAGG

Atp1b2 F TTGAGGAGTGGAAGGAGTTCGTG

$\begin{array}{lll} & \mathrm{R} & \text { CGTGAGGAAACCATAGAAGACGA } \\ \text { Cacna2d2 } & \mathrm{F} & \text { TGCTTTTACCGCTGCTCACC } \\ & \mathrm{R} & \text { TCAAACAGGTTCCGATTGTCCT } \\ \text { Cacna2d3 } & \mathrm{F} & \text { CCGCTTTTGGTGGGGAGAT }\end{array}$

$\begin{array}{lll} & \mathrm{R} & \text { TTGGAGACCGTCGATTTCTTCA } \\ \text { Cacng8 } & \mathrm{F} & \text { CCAACCTCACAGCAGGTGAT } \\ & \mathrm{R} & \text { CAACCCTTCCAGGCAGCATA }\end{array}$

Cox6a2 F CGCCTCCTGACCTTTGTGCT

$\begin{array}{lll}\text { Fgfr4 } & \text { R } & \text { CGGATGCGGAGGTGGTGATA } \\ & \text { F } & \text { GGAGCAGCAAGAGCAGGTGTT }\end{array}$

R CAGGAAGGAAGCTGGCGATCT

$\begin{array}{lll}\text { Fgf8 } & \text { F } & \text { CTCATCCGGACCTACCAGCTCT } \\ & \mathrm{R} & \text { GGGTCTCCGTCTTCTGCCAT }\end{array}$

Fgf12 F GGCGATAGCCAGCTCCTTGA

R TTCAGCTGGGGTTCTGGTCTC

Gnas $\quad \mathrm{F}$ TCTGTGGGAGGATGAGGGAG

$\begin{array}{lll} & \mathrm{R} & \text { TGGTCACTTGGCACGTAGTC } \\ \text { Gsk3b } & \mathrm{F} & \text { CCGAGGAGAGCCCAATGTTT }\end{array}$

R CTGATCCACACCACTGTCCC

Mapk11 F AAACAGTATGGGAGGTGCCG

R AGCTCACGGTATGTCCTCCT

Mapk12 F GTGGTAACCCGGTGGTATCG

R AGGGAGGCCTTCCATGTAGT

Mapk13 F GACAAGATGCTGGAGCTGGA

R GTTTCCATTCGTCCACGCTG

Mapk14 F AACAGGATGCCAAGCCATGA

R GGGTCGTGGTACTGAGCAAA

Map4k1 F GACCAGTGCAGGTGATCCAA

R CAGAGCAGACGGAAGGTGAG
Table I. Continued.

F, forward; R, reverse; Adcy, adenylyl cyclase; Adrb1, adrenoceptor $\beta 1$; Atp1b2, ATPase $\mathrm{Na}+/ \mathrm{K}+$ transporting subunit $\beta 2$; Cacna2d, calcium voltage-gated channel auxiliary subunit $\alpha 2 \delta$; Cacng8, calcium channel voltage-dependent $\gamma$ subunit 8; Cox6a2, cytochrome C oxidase subunit 6A2; Pla2g4a, phospholipase A2 group 4A; Ryr2, ryanodine receptor 2; Fgfr, fibroblast growth factor receptor; Gsk3b, glycogen synthase kinase 3 $\beta$; Mapk, mitogen-activated protein kinase; Map4k1, mitogen-activated protein kinase kinase kinase kinase 1; Pik3ca, phosphatidylinositol-4,5-bisphosphate 3-kinase catalytic subunit $\alpha$; Nos3, nitric oxide synthase 3; Rapgef4, rap guanine nucleotide exchange factor 4 .

\section{Results}

SX treatment attenuates decreases in mitochondrial membrane potential induced by ischemic injury. HL-1 cardiomyocytes in the control, ischemic injury and ischemic injury + SX groups were stained with JC-1 dye and observed under a fluorescence microscope. The area and average density of fluorescence, as indicated by IOD, were evaluated. A red signal indicated a positive (polarized) mitochondrial membrane potential decreased significantly in the ischemic injury group when compared with the control group $(\mathrm{P}<0.001$; Fig. 2). In turn, treatment with SX significantly reversed the decrease in mitochondrial membrane potential in ischemic HL-1 cardiomyocytes ( $\mathrm{P}<0.001$; Fig. 2).

SX treatment attenuates ischemic injury-induced elevations in Adcy2, 3 and $8 \mathrm{mRNA}$, and decreases the levels of Adcyl and $6 m R N A$. mRNA expression in HL-1 cardiomyocytes of the control, ischemic injury and ischemic injury + SX groups was measured by RT-qPCR. Following ischemic injury, significantly increased levels of Adcy2 $(\mathrm{P}<0.05), 3(\mathrm{P}<0.01)$ and $8(\mathrm{P}<0.05)$ mRNA were observed in HL-1 cardiomyocytes (Fig. 3A-C); however, the levels of Adcyl and 8 mRNA did not differ significantly when compared with the control group (Fig. D-E). Treatment with SX significantly attenuated the elevated levels of Adcy2, 3 and 8 mRNA in ischemic cardiomyocytes $(\mathrm{P}<0.01)$, membrane potential. Results indicated that the mitochondrial 

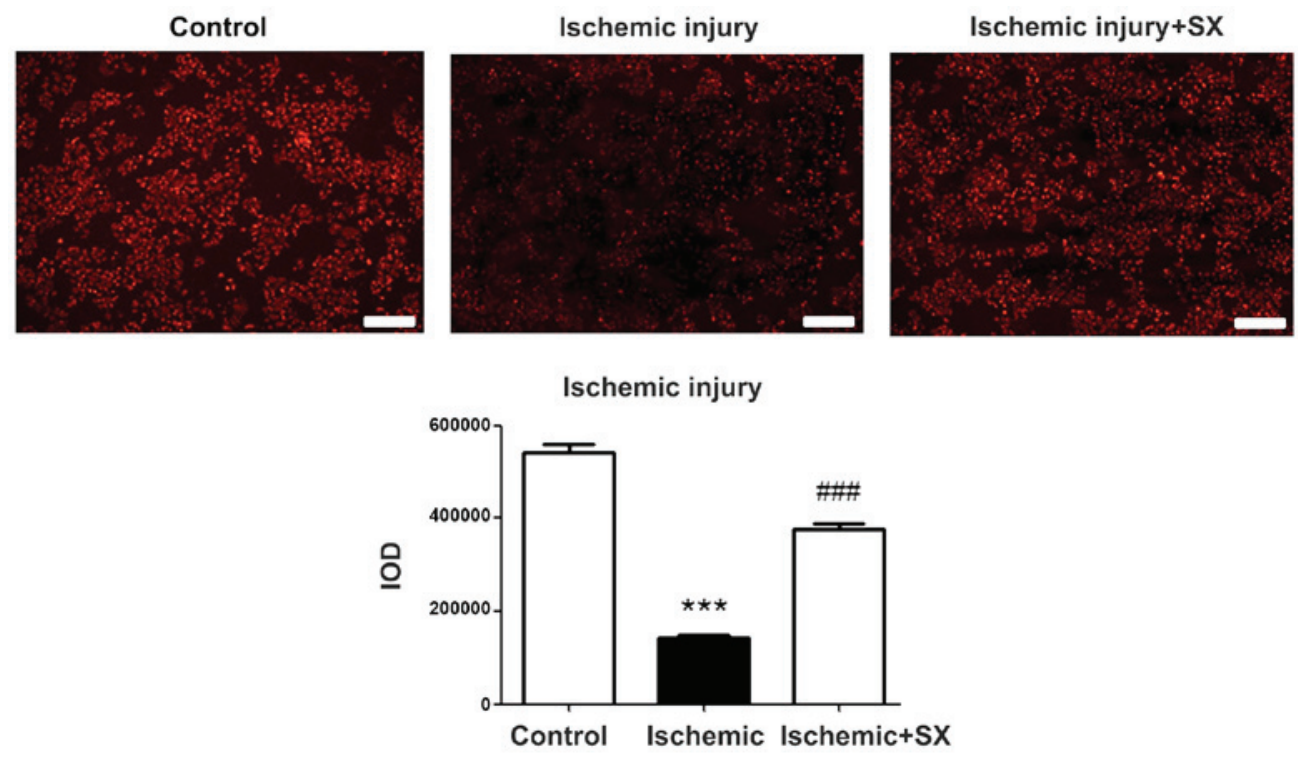

Figure 2. SX treatment attenuated the decrease in mitochondrial membrane potential induced by ischemic injury. HL-1 cardiomyocytes in 3 experimental groups were stained with JC-1 dye (red) and observed under a fluorescence microscope (magnification, $x 100$ ). Data were presented as the mean + standard error of the mean ( $\mathrm{n}=3$ wells/group). Red signal indicated positive (polarized) mitochondrial membrane potential. The mitochondrial membrane potential decreased significantly in the ischemic injury group when compared with the control group, and SX treatment significantly attenuated the decrease in mitochondrial membrane potential in ischemic HL-1 cardiomyocytes. ${ }^{* * *} \mathrm{P}<0.001$ vs. control group; ${ }^{\# \# \#} \mathrm{P}<0.001$ vs. ischemic injury group. Scale bars $=100 \mu \mathrm{m}$. SX, Suxiao Jiuxin Pill; IOD, integrated optical density.
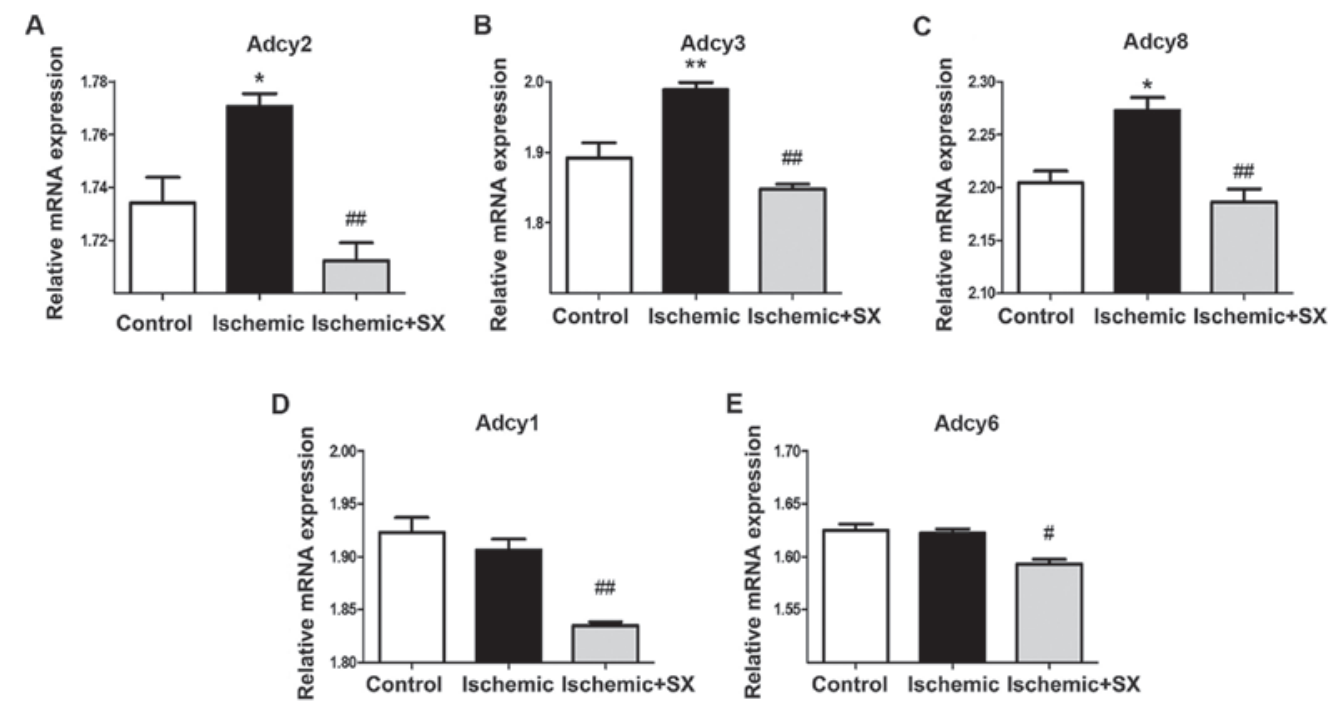

Figure 3. SX treatment attenuated the increase in levels of Adcy2, 3 and 8 mRNA, and decreased the levels of Adcyl and 6 mRNA during ischemic injury. mRNA expression in the 3 experimental groups was detected by reverse transcription-quantitative polymerase chain reaction. The levels of (A) Adcy2, (B) 3 and (C) 8 mRNA in HL-1 cardiomyocytes were significantly increased following ischemic injury, while the levels of (D) Adcyl and (E) 6 mRNA did not differ significantly following ischemia. SX treatment attenuated the increases in Adcy2, 3 and 8 mRNA, and significantly decreased Adcyl and 6 mRNA in the cell culture model of ischemic injury. Data were represented as the mean + standard error of the mean ( $\mathrm{n}=3$ wells/group). ${ }^{*} \mathrm{P}<0.05$ and ${ }^{* *} \mathrm{P}<0.01$ vs. control group; ${ }^{\#} \mathrm{P}<0.05$ and ${ }^{\# \#} \mathrm{P}<0.01$ vs. ischemic injury group. SX, Suxiao Jiuxin Pill.

and also decreased the levels of Adcyl $(\mathrm{P}<0.01)$ and $6(\mathrm{P}<0.05)$ mRNA in ischemic cells (Fig. 3).

SX treatment attenuates ischemic injury-induced reductions in Cox6a2, Gsk3b and Pik3ca mRNA. Significantly decreased levels of Cox6a2 $(\mathrm{P}<0.001)$, Pik3ca $(\mathrm{P}<0.001)$ and Gsk3b $(\mathrm{P}<0.01)$ mRNA were observed in the ischemic injury group when compared with the control group. In turn, treatment with SX significantly reversed the decreases in Cox6a2 $(\mathrm{P}<0.05)$, Pik3ca $(\mathrm{P}<0.001)$ and Gsk3b $(\mathrm{P}<0.01)$ mRNA (Fig. 4).
SX treatment does not alter the levels of Rapgef4, Mapk11, Mapk13, Mapk14 and Fgf8 mRNA in the ischemic injury model. The levels of Rapgef4, Mapk11, Mapk13, Mapk14 and Fgf 8 mRNA were analyzed in the 3 groups. Significantly increased levels of Rapgef4 $(\mathrm{P}<0.05)$, Mapk11 $(\mathrm{P}<0.05)$, Mapk13 $(\mathrm{P}<0.01)$ and Mapk14 $(\mathrm{P}<0.01)$, and significantly decreased levels of Fgf8 mRNA $(\mathrm{P}<0.05)$ were observed in the ischemic injury group when compared with the control group (Fig. 5). However, treatment with SX had no significant effect on the expression of these genes in ischemic 

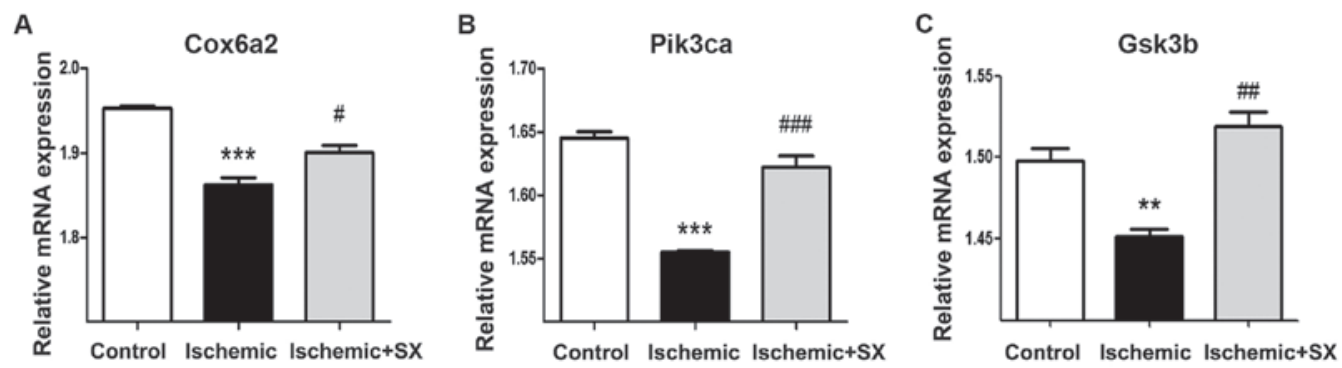

Figure 4. SX treatment attenuated the decrease in Cox6a2, Gsk3b and Pik3ca mRNA in the ischemic injury model. The levels of (A) Cox6a2, (B) Pik3ca and (C) Gsk3b mRNA were significantly decreased in the ischemic injury group when compared with the control group. The decreases in Cox6a2, Gsk3b and Pik3ca mRNA were significantly attenuated by SX treatment. Data were represented as the mean + standard error of the mean ( $\mathrm{n}=3$ wells/group). ${ }^{* *} \mathrm{P}<0.01$ and

${ }^{* * * *} \mathrm{P}<0.001$ vs. the control group; ${ }^{\#} \mathrm{P}<0.05,{ }^{\# \#} \mathrm{P}<0.01$ and ${ }^{\# \# "} \mathrm{P}<0.001$ vs. the ischemic injury group. SX, Suxiao Jiuxin Pill.

A

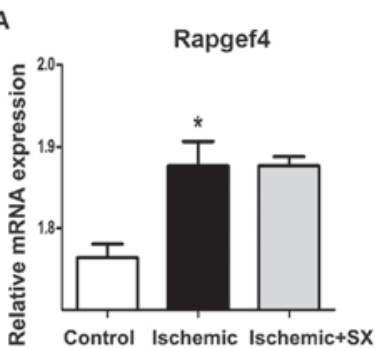

B

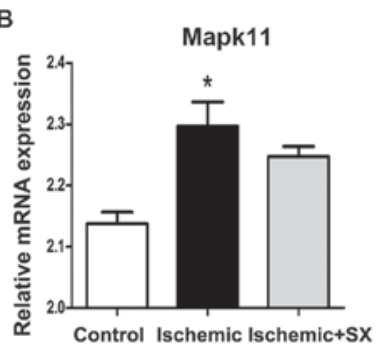

$E$
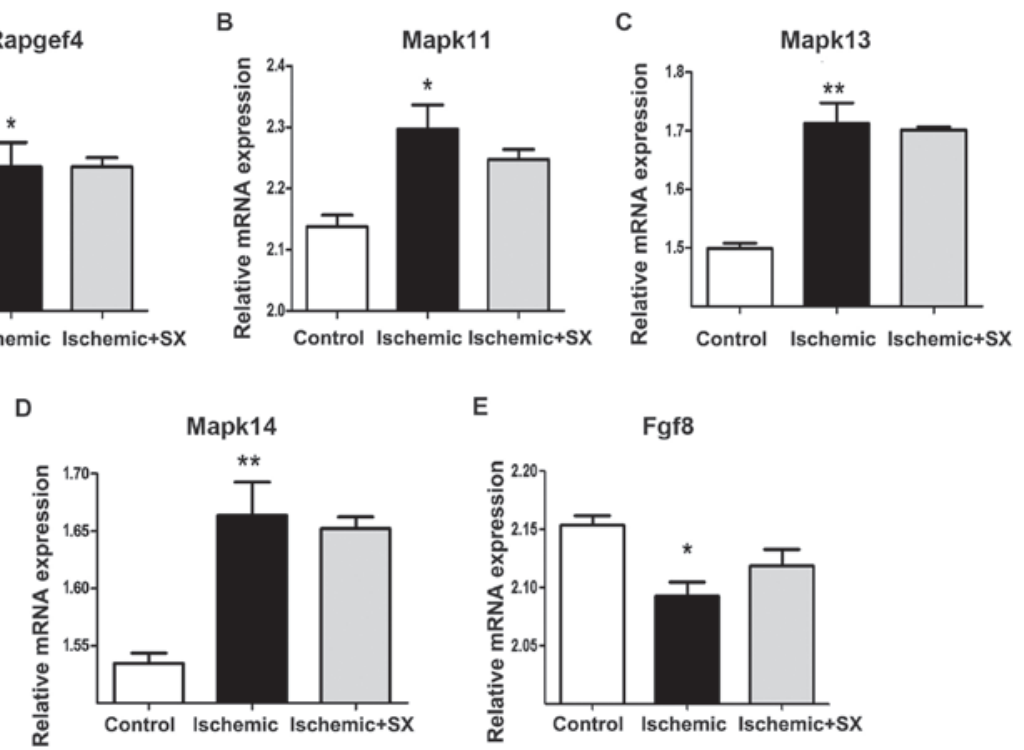

Figure 5. Levels of Rapgef4, Mapk11, Mapk13, Mapk14 and Fgf8 mRNA were not altered by SX treatment in the ischemic injury model. The levels of (A) Rapgef4, (B) Mapk11, (C) Mapk13 and (D) Mapk14 mRNA were significantly increased, and the level of (E) Fgf8 mRNA was significantly decreased in the ischemic injury group when compared with the control group. SX treatment had no significant effect on the expression of these genes in ischemic cardiomyocytes. Data were represented as the mean \pm standard error of the mean ( $\mathrm{n}=3$ wells/group). ${ }^{*} \mathrm{P}<0.05$ and ${ }^{* *} \mathrm{P}<0.01$ vs. the control group. SX, Suxiao Jiuxin Pill.

cardiomyocytes (Fig. 5). Therefore, the statistical differences among 3 groups calculated by ANOVA were caused by differences between ischemic injury and control groups, or differences between ischemic injury $+\mathrm{SX}$ and control groups. In addition, no statistical differences were observed in the mRNA expression levels of Adcy4, Adcy5, Adcy7, Adcy9, Adrb1, Akt1, Atp1b2, Cacna2d2, Cacna2d3, Cacng8, Fgfr4, Fgf12, Gnas, Mapk12, Map4k1, Mas1, Nos3, Pla2g4a and Ryr 2 among the 3 experimental groups (data not shown).

SX treatment attenuates ischemic injury-induced reductions in PI3K, MAS1, and p-eNOS protein expression. The levels of PI3K, MAS1 and p-eNOS protein expression in the 3 experimental groups were examined by immunofluorescence staining. The area and average density of fluorescence, as indicated by IOD, were evaluated. Target proteins were stained green. The protein expression of PI3K was significantly decreased in the ischemic injury group when compared with the control group $(\mathrm{P}<0.001 ;$ Fig. 6), and treatment with SX significantly restored the expression of PI3K to normal levels ( $\mathrm{P}<0.001$; Fig. 6). The levels of MAS1 and p-eNOS did not differ significantly among the 3 groups (Fig. 7).

\section{Discussion}

The present study demonstrated that SX protected cardiomyocytes against mitochondrial injury and attenuated alterations in the expressions of Adcy2, 3 and 8, Cox6a2, Gsk3b and Pik3ca during ischemic injury.

IHD is a significant cause of morbidity and mortality (22). Although therapeutic interventions, including thrombolysis and percutaneous coronary intervention, have proven efficacious in the treatment of ischemic injury, the underlying pathological process of IHD suggests that further protection may be possible (23). The traditional Chinese medicine SX has been implicated as a protective agent against cardiovascular diseases, including IHD and non-IHD diseases (7), and has been reported to inhibit vasoconstriction of human arteries through endothelium-dependent and -independent vasorelaxation (24). Additionally, SX has been indicated to lower blood lipid levels, inhibit the development of atherosclerosis and 

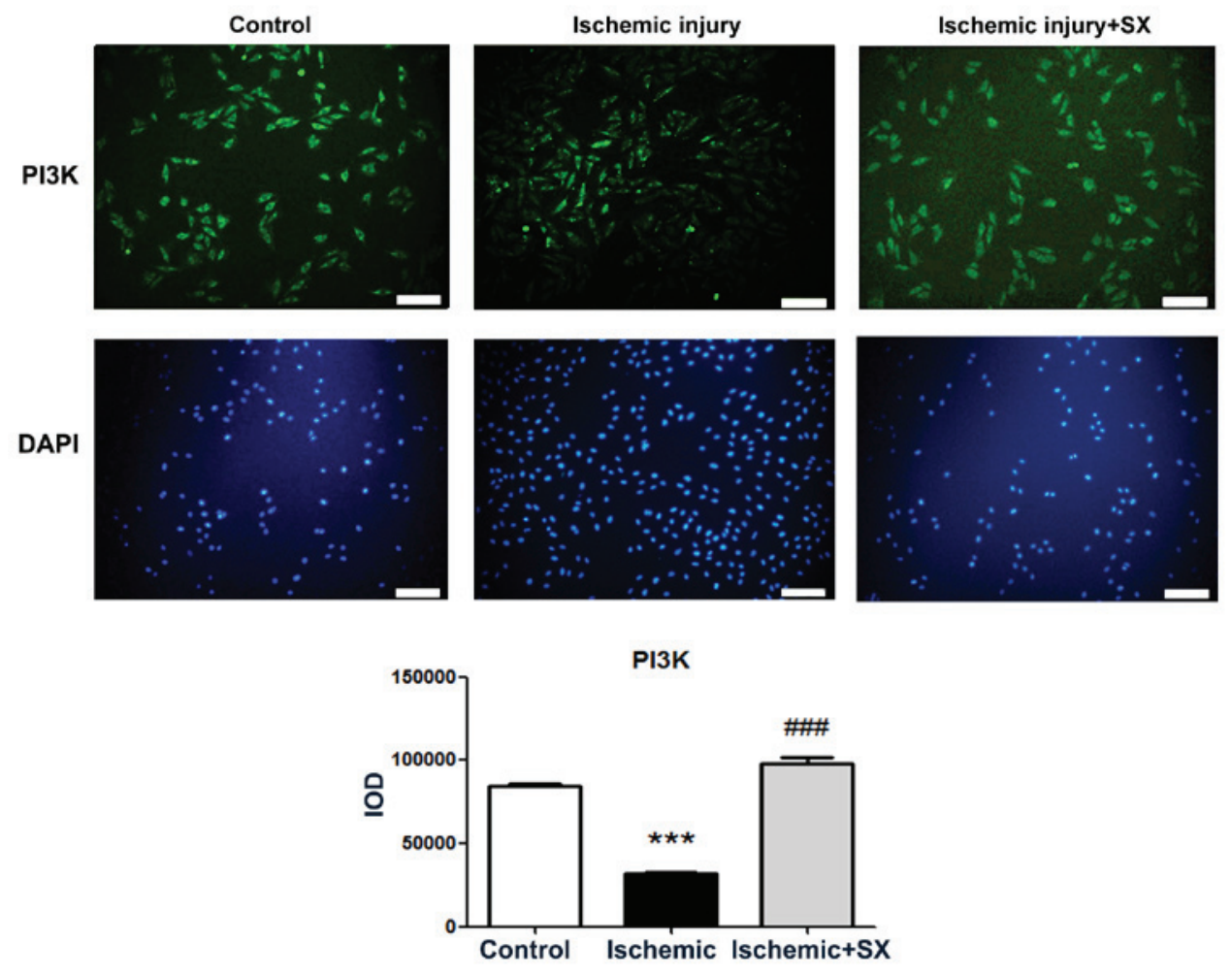

Figure 6. Reduced protein expression of PI3K was attenuated by SX treatment in the ischemic injury model. The levels of PI3K protein expression in the 3 experimental groups were examined by immunofluorescence staining (magnification, $x 100)$. PI3K protein was stained with fluorescein isothiocyanate (green) and cells were counterstained with 4',6-diamidino-2-phenylindole (blue). Data were represented as the mean + standard error of the mean ( $\mathrm{n}=3$ wells/group). The expression levels of PI3K were significantly decreased in the ischemic injury group compared with the control group, whereas SX treatment significantly restored the expression of PI3K to normal levels during ischemic injury. ${ }^{* * *} \mathrm{P}<0.001$ vs. the control group and ${ }^{\# \# \# ~} \mathrm{P}<0.001$ vs. the ischemic injury group. Scale bars $=100 \mu \mathrm{m}$. SX, Suxiao Jiuxin Pill; IOD, integrated optical density.
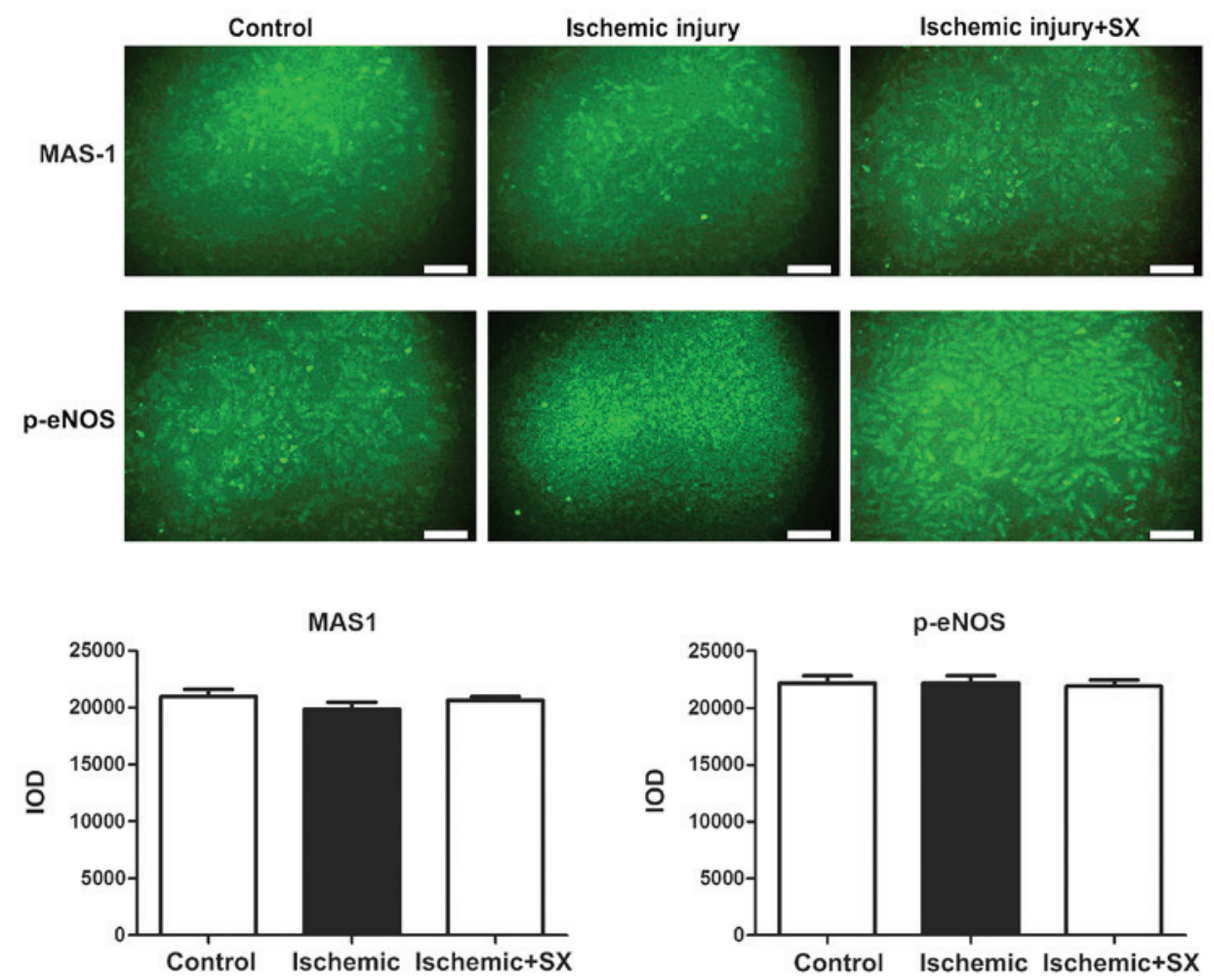

Figure 7. Protein expression of MAS1 and p-eNOS was similar in the 3 experimental groups. The protein expression levels of MAS-1 and p-eNOS in the 3 experimental groups were examined by immunofluorescence staining. The target proteins were stained with fluorescein isothiocyanate (green). No statistical differences in the expression levels of MAS1 and p-eNOS among the 3 groups were identified. Scale bar $=100 \mu \mathrm{m}$. Data were represented as the mean \pm standard error of the mean ( $n=3$ wells/group). SX, Suxiao Jiuxin Pill; IOD, integrated optical density; eNOS, endothelial nitric oxide synthase; p-, phosphorylated. 
suppress inflammatory responses and oxidative stress in rat models of atherosclerosis $(25,26)$.

SX contains tetramethylpyrazine and borneol as its primary components (7). Pretreatment with tetramethylpyrazine has been reported to significantly increase coronary arterial diameter and suppress vasoconstriction mediated by endothelin-1 in rabbits (27). In addition, injection of tetramethylpyrazine induced a significant decrease in plasma endothelin-1 levels (27). A previous study demonstrated that the direct positive inotropic effect of tetramethylpyrazine in rat cardiac myocytes may be associated with production of NO (28). Furthermore, pretreatment with tetramethylpyrazine suppressed vasopressin-induced depression of the $\mathrm{S}$-wave level in a rat model of angina, which was not observed following pretreatment with vehicle alone (saline) (29). This suggested that tetramethylpyrazine ameliorated vasopressin-induced subendocardial ischemia in vivo. However, studies into the effects of borneol on ischemic heart disease are limited, and further research efforts are required to identify the properties of borneol in ischemic injuries.

SX may alter gene or protein expression levels in blood vessels in the absence of ischemic injuries (6). Pretreatment of human internal mammary arteries ex vivo with plasma concentrations of $\mathrm{SX}(1 \mathrm{mg} / \mathrm{ml})$ significantly depressed maximal contraction to $\mathrm{KCl}$ and $\mathrm{U} 46619$, and when $10 \mathrm{mg} / \mathrm{ml}$ SX was applied, the subsequent contraction was abolished (6). However, it is unclear whether SX alone alters gene and protein expression in cardiomyocytes in the absence of ischemic injuries, and further studies are required to investigate this.

Mitochondria in the heart serve two roles that are essential for cell survival: ATP synthesis and maintenance of $\mathrm{Ca}^{2+}$ homeostasis (30). Although mitochondria do not regulate cytosolic $\mathrm{Ca}^{2+}$ under aerobic physiologic conditions (31), mitochondrial $\mathrm{Ca}^{2+}$ overload alters intracellular $\mathrm{Ca}^{2+}$ homeostasis and causes an overload cycle that result in irreversible cell damage during IHD (31). Activated soluble guanylate cyclase has been demonstrated to protect against post-ischemic mitochondrial inflammation in mice by reducing phosphorylated cyclophilin D and the formation of mitochondrial permeability transition pores (32). In addition, fatty acid nitroalkenes have been reported to induce resistance to ischemic cardiac injury in rat heart mitochondria, by suppressing superoxide formation and reversibly inhibiting complex II-linked respiration in a pH-dependent manner (33). Furthermore, the mitochondrial $\mathrm{K}_{\mathrm{ATP}}$ channel serves a critical role in cardioprotection during cardiac ischemia (34). In the present study, it was observed that SX treatment protected against damage to the mitochondrial membrane potential in an ischemic injury model. Further research is now required to fully elucidate the mechanisms underlying this protection, which may involve mitochondrial permeability transition pores, mitochondrial complexes, the $\mathrm{K}_{\text {ATP }}$ channel and reactive oxygen species.

In the present study, the increased levels of Adcy2, 3 and 8 mRNA in the ischemic injury model were significantly attenuated by SX treatment, and the levels of Adcyl and 6 mRNA were significantly decreased following SX treatment. Adcy proteins (encoded by the Adcy gene) catalyze the conversion of ATP to cyclic adenosine monophosphate (cAMP) (35). Adcys are activated or inhibited by guanine nucleotide binding proteins ( $\mathrm{G}$ proteins), which are coupled to membrane receptors that respond to hormonal stimulations, among others (35).
cAMP, as a second messenger, serves as a regulatory signal through its interactions with cAMP-binding proteins, including protein kinase $\mathrm{A}$, ion channels, transcription factors and enzymes $(36,37)$.

ADCY2 protein, encoded by the Adcy 2 gene, accelerates phosphor-acidification and the synthesis and breakdown of glycogen (35). Abnormal ADCY2 protein has been implicated in chronic obstructive pulmonary disease and bipolar disorder $(38,39)$. Upregulation of the ADCY3 protein (encoded by the Adcy 3 gene) has been indicated to increase the tumorigenic potential of cells by activating the cAMP response element binding protein pathway (40). The calmodulin-stimulated ADCY 8 protein (encoded by the Adcy8 gene) has been reported to regulate the sensitivity of zebrafish retinal axons to midline repellents, and is required for normal midline crossing (41). Furthermore, ADCY8 is associated with mouse avoidance behavior and human mood disorder (42). Mutations in ADCY1 (encoded by the Adcyl gene) have been reported to cause recessive hearing impairment in humans and defects in hair cell function and hearing in zebrafish (43), and mutations in contactin associated protein 1 and ADCY6 (encoded by the Adcy6 gene) may be responsible for severe arthrogryposis multiplex congenita with axoglial defects (44). To the best of our knowledge, the present study demonstrated for the first time that the mRNA expressions of Adcy2, 3 and 8 were significantly increased during ischemic injury, which was significantly attenuated by SX treatment. In addition, the expressions of Adcyl and 6 were significantly decreased following SX treatment. These findings suggest potential molecular mechanisms involved in ischemic injury and indicate the possible pharmaceutical targets of SX treatment.

The present study also demonstrated that the significant decreases in Gsk3b and Pik3ca mRNA in ischemic injury were significantly attenuated by SX treatment. In Fig. 6, although the cell number appeared larger in ischemic injury group, IOD of PI3K (encoded by the Pik3ca gene) was lower in ischemic injury group when compared with control and SX treatment groups. Alterations in the protein expression of PI3K following SX treatment were also investigated by immunofluorescence. COX6A2 (encoded by the Cox6a 2 gene) is the last enzyme in the respiratory electron transport chain of the mitochondrial membrane (45). GSK3 $\beta$ (encoded by the Gsk3b gene) phosphorylates glycogen synthase and is active in a number of intracellular signaling pathways, including cell proliferation, migration and glucose regulation (46). The PI3K protein (encoded by the Pik3ca gene) is involved in cell differentiation, motility, survival and intracellular trafficking (47). The significant decrease in Cox6a 2 mRNA in cardiomyocytes indicated that the mitochondrial membrane was damaged during ischemic injury. Furthermore, the decrease in Gsk3b mRNA indicated that the energy storage and proliferative capacities of cell were impeded during ischemic injury. In addition, the significant decrease in Pik3ca mRNA suggested that cell differentiation and survival was impaired during ischemic injury. The present study demonstrated that SX treatment significantly alleviated the decreases in Cox6a2, Gsk3b and Pik3ca mRNA during ischemic injury. These findings may in part explain the protective effects of SX in the treatment of ischemic cardiac injury. 
Treatment with SX had no apparent effect on the expression of genes associated with membrane structures and signals, with the exceptions of Adcy2, 3 and 8 and Cox6a2. ADR $\beta 1$ (encoded by the Adrb1 gene) is a G-protein-coupled receptor expressed predominantly in cardiac tissue (48). G proteins (encoded by the Gnas gene) are important signal transducing molecules in cells (49). $\mathrm{Na}^{+} / \mathrm{K}^{+}$-ATPase (encoded by the Atp1b2 gene) maintain resting potential and effective transport, and regulate cellular volume (50). Furthermore, $\mathrm{CACN} \alpha 2 \delta$ channels (encoded by the Cacna2d2, Cacna2d3 and Cacng8 genes) are present in the membrane of excitable cells, including that of cardiac muscle (51). Cardiac RYR2 (encoded by the Ryr2 gene) mediates the sarcoplasmic release of stored calcium ions during cardiac calcium-induced calcium release (52). PLA2 (encoded by the Pla2g4a gene) hydrolyzes phospholipids into arachidonic acid and mediates inflammation (53). In the present study, SX treatment exhibited no significant effect on the aforementioned structural proteins.

Treatment with SX also had no apparent effect on the expression of genes associated with cell proliferation, with the exceptions of Gsk3b and Pik3ca. The serine/threonine kinase AKT (encoded by the Aktl gene) phosphorylates and inactivates components involved in apoptosis (54). FGFRs (encoded by the Fgfr4, 8 and 12 genes) regulate key biological processes, including cell proliferation and differentiation during development and tissue repair (55). MAPK (encoded by the Mapk11, 12, 13 and 14 genes) and MAP4K1 (encoded by the Map4k1 gene) regulate cell functions, including proliferation, mitosis, cell survival and apoptosis (56). MAS1 (encoded by the Mas1 gene) modulates the growth-regulating pathway when activated (57). In the present study, SX treatment exhibited no significant effect on the aforementioned proteins involved in cell proliferation.

Treatment with SX did not alter the expression of genes associated with vasodilation and muscle relaxation in the present study. The eNOS protein (encoded by the Nos3 gene) is responsible for the generation of NO in the vascular endothelium (58), and RAPGEF4 (encoded by the Rapgef4 gene) is associated with glucagon-like peptide-stimulated secretion of atrial natriuretic peptide in the heart (59). In the present study, the aforementioned proteins were not altered significantly by SX treatment.

In conclusion, SX protected cardiomyocytes against mitochondrial injury, and attenuated alterations in the expressions of Adcy2, 3 and 8, Cox6a2, Gsk3b and Pik3ca during ischemic injury.

\section{Acknowledgements}

The present study was supported by the National Natural Science Foundation of China (grant nos. 81403352 and 81573647).

\section{References}

1. Elosua R and Sayols-Baixeras S: The genetics of ischemic heart disease: From current knowledge to clinical implications. Rev Esp Cardiol (Engl Ed): Jun 13, 2017 (Epub ahead of print) (In English, Spanish).

2. Buxton AE: Sudden death in ischemic heart disease-2017. Int J Cardiol 237: 64-66, 2017.

3. Wong ND: Epidemiological studies of CHD and the evolution of preventive cardiology. Nat Rev Cardiol 11: 276-289, 2014.
4. Lozano R, Naghavi M, Foreman K, Lim S, Shibuya K, Aboyans V, Abraham J, Adair T, Aggarwal R, Ahn SY, et al: Global and regional mortality from 235 causes of death for 20 age groups in 1990 and 2010: A systematic analysis for the global burden of disease study 2010. Lancet 380: 2095-2128, 2012.

5. Nobre MRC and Domingues RZL: Patient adherence to ischemic heart disease treatment. Rev Assoc Med Bras (1992) 63: 252-260, 2017.

6. Wang XL, Liu YM and Zhu GJ: Effects of suxiao jiuxin pill on patients with acute coronary syndrome undergoing early percutaneous coronary intervention. Zhongguo Zhong Xi Yi Jie He Za Zhi 32: 1483-1487, 2012 (In Chinese).

7. Duan X, Zhou L, Wu T, Liu G, Qiao J, Wei J, Ni J, Zheng J, Chen $\mathrm{X}$ and Wang Q: Chinese herbal medicine suxiao jiuxin wan for angina pectoris. Cochrane Database Syst Rev: CD004473, 2008.

8. Lu Z, Zhang Y, Zhuang P, Zhang J, Zhou H, Zhang M, Yang X, Wang J, Liu D and Tong Y: Protective effect of Suxiao jiuxin pill, a traditional Chinese medicine, against acute myocardial ischemia in dogs. BMC Complement Altern Med 15: 373, 2015.

9. Al Rahim M, Thatipamula S and Hossain MA: Critical role of neuronal pentraxin 1 in mitochondria-mediated hypoxic-ischemic neuronal injury. Neurobiol Dis 50: 59-68, 2013.

10. Shoshan-Barmatz V, Krelin Y and Chen Q: VDAC1 as a player in mitochondria-mediated apoptosis and target for modulating apoptosis. Curr Med Chem: Jun 16, 2017 (Epub ahead of print).

11. Wang H, Sun X, Chou J, Lin M, Ferrario CM, Zapata-Sudo G and Groban L: Cardiomyocyte-specific deletion of the G protein-coupled estrogen receptor (GPER) leads to left ventricular dysfunction and adverse remodeling: A sex-specific gene profiling analysis. Biochim Biophys Acta 1863: 1870-1882, 2017.

12. Valsecchi F, Konrad C and Manfredi G: Role of soluble adenylyl cyclase in mitochondria. Biochim Biophys Acta 1842: 2555-2560, 2014.

13. Björck ML, Zhou S, Rydström Lundin C, Ott M, Ädelroth P and Brzezinski P: Reaction of S. cerevisiae mitochondria with ligands: Kinetics of $\mathrm{CO}$ and $\mathrm{O} 2$ binding to flavohemoglobin and cytochrome c oxidase. Biochim Biophys Acta 1858: 182-188, 2017.

14. Min CK, Yeom DR, Lee KE, Kwon HK, Kang M, Kim YS, Park ZY, Jeon H and Kim DH: Coupling of ryanodine receptor 2 and voltage-dependent anion channel 2 is essential for $\mathrm{Ca}^{2}+$ transfer from the sarcoplasmic reticulum to the mitochondria in the heart. Biochem J 447: 371-379, 2012.

15. Cai K, Wang B, Dou H, Luan R, Bao X and Chu J: IL-17A promotes the proliferation of human nasopharyngeal carcinoma cells through p300-mediated Akt1 acetylation. Oncol Lett 13: 4238-4244, 2017

16. Li JY, Liu SG, Xiao GN, Mao MY, Zhang XW and Sun HQ: Fibroblast growth factor receptor 1 propagates estrogen and fluid shear stress driven proliferation and differentiation response in MC3T3-E1 cells. Mol Biol (Mosk) 51: 342-355, 2017 (In Russian).

17. Cui B, Jin J, Ding X, Deng M, Yu S, Song M, Yu Y, Zhao X, Chen $J$ and Huang L: Glycogen synthase kinase $3 \beta$ inhibition enhanced proliferation, migration and functional re-endothelialization of endothelial progenitor cells in hypercholesterolemia microenvironment. Exp Biol Med (Maywood) 240: 1752-1763, 2015.

18. Djordjevic VB, Stojanovic I, Cosic V, Zvezdanovic L, Deljanin-Ilic M, Dimic S, Kundalic B, Cvetkovic T and Jevtovic-Stoimenov T: Serum neopterin, nitric oxide, inducible nitric oxide synthase and tumor necrosis factor-alpha levels in patients with ischemic heart disease. Clin Chem Lab Med 46: 1149-1155, 2008

19. Lee SJ and Han JK: XEpac, a guanine nucleotide-exchange factor for Rap GTPase, is a novel hatching gland specific marker during the Xenopus embryogenesis. Dev Dyn 232: 1091-1097, 2005.

20. Tee YT, Han CP, Ko JL, Chen GD, Yang SF, Chen SC, Tsai HJ, Lin LY and Wang PH: Evaluation of matrix metalloproteinase 2 expression in cervical carcinogenesis using tissue array and integrated optical density for immunoreactivity. Reprod Sci 14: 719-726, 2007.

21. Livak KJ and Schmittgen TD: Analysis of relative gene expression data using real-time quantitative PCR and the 2(-Delta Delta C(T)) method. Methods 25: 402-408, 2001

22. Writing Group M, Mozaffarian D, Benjamin EJ, Go AS, Arnett DK, Blaha MJ, Cushman M, Das SR, de Ferranti S, Després JP, et al: Heart disease and stroke statistics-2016 update: A report from the American heart association. Circulation 133: e38-e360, 2016. 
23. Ujueta F, Weiss EN, Shah B and Sedlis SP: Effect of percutaneous coronary intervention on survival in patients with stable ischemic heart disease. Curr Cardiol Rep 19: 17, 2017.

24. Bai XY, Zhang P, Yang Q, Liu XC, Wang J, Tong YL, Xiong SJ, Liu LH, Wang L and He GW: Suxiao jiuxin pill induces potent relaxation and inhibition on contraction in human artery and the mechanism. Evid Based Complement Alternat Med 2014: 956924, 2014.

25. Guo QX, Zhang J, Li YQ and Zhang GF: Study on anti-atherosclerotic effect of Suxiao Jiuxin Pill and its mechanism. Afr J Tradit Complement Altern Med 11: 97-102, 2013.

26. L i CS, Qu ZQ, Wang SS, Hao XW, Zhang XQ, Guan J and Han F: Effects of suxiao jiuxin pill (see test) on oxidative stress and inflammatory response in rats with experimental atherosclerosis. J Tradit Chin Med 31: 107-111, 2011.

27. Zeng Z, Zhu W, Zhou X, Jin Z, Liu H, Chen X, Pan J, Demura H, Naruse $M$ and Shi Y: Tetramethylpyrazine, a Chinese drug, blocks coronary vasoconstriction by endothelin-1 and decreases plasma endothelin-1 levels in experimental animals. J Cardiovasc Pharmacol 31 (Suppl 1): S313-S316, 1998.

28. Hintz KK and Ren J: Tetramethylpyrazine elicits disparate responses in cardiac contraction and intracellular $\mathrm{Ca}(2+)$ transients in isolated adult rat ventricular myocytes. Vascul Pharmacol 40: 213-217, 2003.

29. Cao X, Nakamura Y, Wada T, Kishie T, Enkhsaikhan A, Izumi-Nakaseko H, Ando K, Zhu B, Xu B and Sugiyama A: Assessment of the anti-anginal effect of tetramethylpyrazine using vasopressin-induced angina model rats. Biol Pharm Bull 39: 1370-1373, 2016.

30. Kozlov AV, Lancaster JR Jr, Meszaros AT and Weidinger A: Mitochondria-meditated pathways of organ failure upon inflammation. Redox Biol 13: 170-181, 2017.

31. Ferrari R: The role of mitochondria in ischemic heart disease. J Cardiovasc Pharmacol 28 (Suppl 1): S1-S10, 1996.

32. Wang DZ, Jones AW, Wang WZ, Wang M and Korthuis RJ: Soluble guanylate cyclase activation during ischemic injury in mice protects against postischemic inflammation at the mitochondrial level. Am J Physiol Gastrointest Liver Physiol 310: G747-G756, 2016.

33. Koenitzer JR, Bonacci G, Woodcock SR, Chen CS, Cantu-Medellin N, Kelley EE and Schopfer FJ: Fatty acid nitroalkenes induce resistance to ischemic cardiac injury by modulating mitochondrial respiration at complex II. Redox Biol 8: 1-10, 2016.

34. Murata M, Akao M, O'Rourke B and Marbán E: Mitochondrial ATP-sensitive potassium channels attenuate matrix $\mathrm{Ca}(2+)$ overload during simulated ischemia and reperfusion: Possible mechanism of cardioprotection. Circ Res 89: 891-898, 2001.

35. Li YX, Jin HG, Yan CG, Ren CY, Jiang CJ, Jin CD, Seo KS and Jin X: Molecular cloning, sequence identification, and gene expression analysis of bovine ADCY2 gene. Mol Biol Rep 41: 3561-3568, 2014.

36. Ahmad JN, Cerny O, Linhartova I, Masin J, Osicka R and Sebo P: cAMP signalling of Bordetella adenylate cyclase toxin through the SHP-1 phosphatase activates the BimEL-Bax pro-apoptotic cascade in phagocytes. Cell Microbiol 18: 384-398, 2016.

37. Fukuchi M,Kuwana Y, Tabuchi A and Tsuda M: Balance between cAMP and $\mathrm{Ca}(2+)$ signals regulates expression levels of pituitary adenylate cyclase-activating polypeptide gene in neurons. Genes Cells 21: 921-929, 2016

38. Hardin M, Zielinski J, Wan ES, Hersh CP, Castaldi PJ Schwinder E, Hawrylkiewicz I, Sliwinski P, Cho MH and Silverman EK: CHRNA3/5, IREB2, and ADCY2 are associated with severe chronic obstructive pulmonary disease in Poland. Am J Respir Cell Mol Biol 47: 203-208, 2012.

39. Xu W, Cohen-Woods S, Chen Q, Noor A, Knight J, Hosang G, Parikh SV, De Luca V, Tozzi F, Muglia P, et al: Genome-wide association study of bipolar disorder in Canadian and UK populations corroborates disease loci including SYNE1 and CSMD1. BMC Med Genet 15: 2, 2014

40. Hong SH, Goh SH, Lee SJ, Hwang JA, Lee J, Choi IJ, Seo H, Park JH, Suzuki H, Yamamoto E, et al: Upregulation of adenylate cyclase 3 (ADCY3) increases the tumorigenic potential of cells by activating the CREB pathway. Oncotarget 4: 1791-1803, 2013.

41. Xu H, Leinwand SG, Dell AL, Fried-Cassorla E and Raper JA: The calmodulin-stimulated adenylate cyclase ADCY8 sets the sensitivity of zebrafish retinal axons to midline repellents and is required for normal midline crossing. J Neurosci 30: 7423-7433, 2010.
42. de Mooij-van Malsen AJ, van Lith HA, Oppelaar H, Hendriks J, de Wit M, Kostrzewa E, Breen G, Collier DA, Olivier B and Kas MJ: Interspecies trait genetics reveals association of Adcy8 with mouse avoidance behavior and a human mood disorder. Biol Psychiatry 66: 1123-1130, 2009.

43. Santos-Cortez RL, Lee K, Giese AP, Ansar M, Amin-Ud-Din M, Rehn K, Wang X, Aziz A, Chiu I, Hussain Ali R, et al: Adenylate cyclase 1 (ADCY1) mutations cause recessive hearing impairment in humans and defects in hair cell function and hearing in zebrafish. Hum Mol Genet 23: 3289-3298, 2014.

44. Laquérriere A, Maluenda J, Camus A, Fontenas L, Dieterich K, Nolent F, Zhou J, Monnier N, Latour P, Gentil D, et al: Mutations in CNTNAP1 and ADCY6 are responsible for severe arthrogryposis multiplex congenita with axoglial defects. Hum Mol Genet 23: 2279-2289, 2014.

45. Quintens R, Singh S, Lemaire K, De Bock K, Granvik M, Schraenen A, Vroegrijk IO, Costa V, Van Noten P, Lambrechts D, et al: Mice deficient in the respiratory chain gene Cox6a 2 are protected against high-fat diet-induced obesity and insulin resistance. PLoS One 8: e56719, 2013.

46. Nishimura H, Nakamura O, Yamagami Y, Mori M, Horie R, Fukuoka N and Yamamoto T: GSK-3 inhibitor inhibits cell proliferation and induces apoptosis in human osteosarcoma cells. Oncol Rep 35: 2348-2354, 2016.

47. Lien EC, Dibble CC and Toker A: PI3K signaling in cancer: Beyond AKT. Curr Opin Cell Biol 45: 62-71, 2017.

48. Wei W, Tian Y, Zhao C, Sui Z, Liu C, Wang C and Yang R: Correlation of ADRB1 rs1801253 polymorphism with analgesic effect of fentanyl after cancer surgeries. Med Sci Monit 21: 4000-4005, 2015.

49. Wootten D, Miller LJ, Koole C, Christopoulos A and Sexton PM: Allostery and biased agonism at class B G protein-coupled receptors. Chem Rev 117: 111-138, 2017.

50. Stecyk JA, Farrell AP and Vornanen M: Na+/K+-ATPase activity in the anoxic turtle (Trachemys scripta) brain at different acclimation temperature. Comp Biochem Physiol A Mol Integr Physiol 206: 11-16, 2017.

51. Ivanov SV, Ward JM, Tessarollo L, McAreavey D, Sachdev V, Fananapazir L, Banks MK, Morris N, Djurickovic D, Devor-Henneman DE, et al: Cerebellar ataxia, seizures, premature death, and cardiac abnormalities in mice with targeted disruption of the Cacna2d2 gene. Am J Pathol 165: 1007-1018, 2004.

52. Kato T, Yamamoto T, Nakamura Y, Nanno T, Fukui G, Sufu Y, Hamada Y, Maeda T, Nishimura S, Ishiguchi $\mathrm{H}$, et al: Correction of impaired calmodulin binding to RyR2 as a novel therapy for lethal arrhythmia in the pressure-overloaded heart failure. Heart Rhythm 14: 120-127, 2017.

53. Marsche G: Lp-PLA2, plaque inflammation and lesion development vary fundamentally between different vascular sites. J Am Heart Assoc 4: pii: e001800, 2015.

54. Gong H, Cao Y, Han G, Zhang Y, You Q, Wang Y and Pan Y: p53/microRNA-374b/AKT1 regulates colorectal cancer cell apoptosis in response to DNA damage. Int J Oncol 50: 1785-1791, 2017.

55. Zhang J, Zhu LX, Cheng X, Lin Y, Yan P and Peng B: Promotion of dental pulp cell migration and pulp repair by a bioceramic putty involving FGFR-mediated signaling pathways. J Dent Res 94: 853-862, 2015.

56. Pearson G, Robinson F, Beers Gibson T, Xu BE, Karandikar M, Berman K and Cobb MH: Mitogen-activated protein (MAP) kinase pathways: Regulation and physiological functions. Endocr Rev 22: 153-183, 2001.

57. Hoffmann BR, Stodola TJ, Wagner JR, Didier DN, Exner EC, Lombard JH and Greene AS: Mechanisms of Mas1 receptor-mediated signaling in the vascular endothelium. Arterioscler Thromb Vasc Biol 37: 433-445, 2017.

58. Charoensin S, Eroglu E, Opelt M, Bischof $\mathrm{H}$, Madreiter-Sokolowski CT, Kirsch A, Depaoli MR, Frank S, Schrammel A, Mayer B, et al: Intact mitochondrial Ca2+ uniport is essential for agonist-induced activation of endothelial nitric oxide synthase (eNOS). Free Radic Biol Med 102: 248-259, 2017.

59. Kim M, Platt MJ, Shibasaki T, Quaggin SE, Backx PH, Seino S, Simpson JA and Drucker DJ: GLP-1 receptor activation and Epac2 link atrial natriuretic peptide secretion to control of blood pressure. Nat Med 19: 567-575, 2013. 